\title{
AYKAÇ, Onur (2019). Geçmişten Günümüze Ortaoyunu Geleneği. Ankara: Akçă̆ Yayınları. 255 s.
}

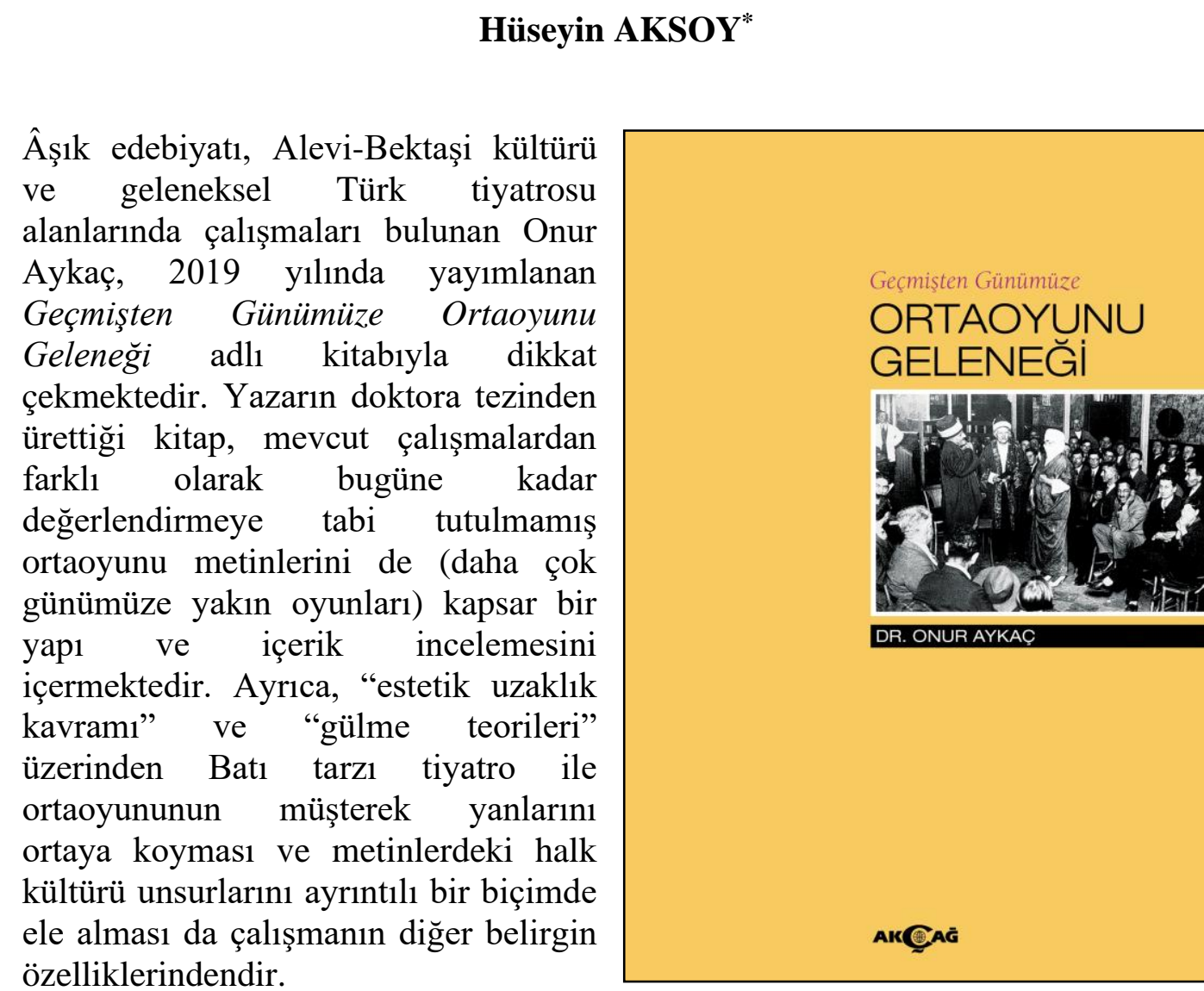

Aykaç, bu çalışmada özellikle son dönem ortaoyunu metin külliyatını tespit etmekte, ortaoyunu geleneğine ait eski ve yeni metinleri bir arada değerlendirerek bunları yer yer birbirleriyle karşılaştırmakta, bu sayede geleneğin geçirdiği değişim hakkında çıkarımlarda bulunmaktadır. Diğer taraftan ortaoyununu yenileştirme ve yaşatma çabası içinde olanların görüşlerini özenle incelediği, ortaoyunu geleneğini geleceğe taşımak için yapılması gerekenleri detaylı olarak tartıştığı da görülmektedir.

Kitabın kapağı, ortaoyunu geleneğini yansıtan bir fotoğrafla süslenmiştir. Fotoğrafta, 1930'lu yıllarda Şehzadebaşı Letafet Apartmanı'nda oynanan bir ortaoyunu temsili görülmektedir. Kitabın ilk sayfalarında ise, Aykaç'ın doktora döneminde ders alıp bilgilerinden istifade ettiği üç hocası için yazdığı ithaf cümlesi okurları karşılamaktadır.

\footnotetext{
*Dr., Karamanoğlu Mehmetbey Üniversitesi, Edebiyat Fakültesi, Türk Dili ve Edebiyatı Bölümü. e-posta: $\underline{\text { h.aksoy@kmu.edu.tr }}$
} 
Çalışma her ne kadar yazarın doktora tezinden üretilmiş olsa da, tezden farklı olarak Mehmet Akan'ın "Midirfillik Oyunu” ile Umut Uğur'un “Kabakçı Mustafa Vakası" oyunu da sonradan çalışmaya dâhil edilmiştir. Bu durum, Aykaç'ın ortaoyunu üzerine araştırmalarını hâlâ sürdürdügüünü göstermektedir. Yine tezden farklı olarak Utku Erişik, Hasan Hüseyin Karabağ ve Alpay Ekler ile yapılan röportajlar da çalışmaya ilave edilmiştir. Türk halk tiyatrosunun bugünkü konumu, tiyatronun işlevi gibi hususların bu röportajlarda etraflıca konuşulduğu görülmektedir.

Aykaç'ın çalışması, “Giriş” bölümü dışında üç ana bölümden oluşmaktadır. Kitabın "Giriş" kısmı (ss. 1-17) ortaoyunu ile ilgili kitaplar, kitap bölümleri, tezler, makaleler, sözlük ve ansiklopedi maddelerinin tanıtımına ayrılmış; ayrıca yayımlanmış ortaoyunu metinlerinin künyeleri de burada sıralanmıştır. Böylece yazar, üzerinde çalıştığı konuyla ilgili daha önce yapılmış çalışmaları değerlendirerek söz söyleyecek yeni alanlar saptamıştır.

Kitabın birinci bölümü (ss. 19-108), “Ortaoyununun Genel Özellikleri” başlığını taşımaktadır. Ortaoyununun kökeni ve tarihî gelişimi, oyuncu kolları, oyun dağarcığı, yapısı, tipleri, dekoru, barındırdığg musiki ve raks unsurları, dil ve anlatımı, önde gelen temsilcileri bu bölümde mevcut çalışmalardan hareketle ele alınmış; Cumhuriyet döneminde ortaoyununu yenileştirme ve yaşatma çabası içine girenlerin faaliyetleri detaylı olarak irdelenmiştir. Bu bölümde, Aykaç'ın özellikle ortaoyunu geleneğinin yaşatılması için sunduğu öneriler ön plana çıkmaktadır. İlk olarak geçmişten günümüze pek çok araştırmacının önerilerine yer veren Aykaç, tüm önerilerin ortak noktasını "temsillerin içeriğini çağa uygun hâle getirme ve ortaoyunuyla Batılı tiyatroyu kaynaştırma" olarak tespit etmiş; ardından konuyla ilgili kendi fikirlerini şu şekilde aktarmıştır: "Ortaoyunu geleneği; 'yenileştirme çabaları' adı altında özünden uzaklaştırmamalı, gerekirse 'müzelik bir eşya' gibi korunmalı ve sadece özel günlerde halk önüne çıkarılmalıdır. Adı 'ortaoyunu' olan, ancak kendisi bu geleneğin çok uzağında bulunan temsiller, bugünün insanlarına 'ortaoyunu' kisvesi altında sunulmamalıdır. Devletin ilgili kurumlarının özel projeler üretmesi ve yazarların ortaoyunuyla Batılı tiyatroyu kaynaştıran oyunlar kaleme alması, bu geleneği geleceğe taşıma umutlarını daha taze tutabilir" (Aykaç, 2019: 95). Aykaç'ın geleneğin güncellenmesi hakkındaki fikirleri, folklorist Benjamin A. Botkin'den alıntı yapan Dan Ben-Amos'un folklor ile ilgili görüşlerini hatırlatmaktadır. Ona göre "folklor, yeni şişelerde eski şarap olabileceği gibi eski şişelerde de taze şarap olabilir. Fakat o, çok nadir olarak yeni şişelerde taze şarap gibi tasavvur edilmiştir." (Ben-Amos, 2006: 40-41)

Aykaç'ın, birinci bölümde mevcut çalışmalardan hareket ettiğini ve bilinen bilgileri harmanladığını söylerken bir hususu ifade etmekte fayda vardır. Aykaç, mevcut kaynaklarda zikredilen bilgileri sorgulamadan çalışmasına dâhil etmemiştir. Bunun en güzel örneği, Sünbül-zâde Vehbi'nin Divan'ına atfen yapılan yanlışı düzelttiği şu cümlelerinde görülebilir: "Bazı araştırmacılar, Sünbül-zâde Vehbi'nin Divan'ında geçen 'Ortaya düşdüm deyü gâhî miyânın 
kollayıp/ Ol kul oglunun gehi boynuna kol salmalıdır' beytindeki 'kul oğlu' ifadesini sehven yanlış okuyarak 'kol oğlu' şeklinde ele almışlar ve bu beyitte ortaoyunu kollarının kastedildiğini söylemişlerdir. Hatta beytin başında geçen 'ortaya düşmek' ifadesindeki 'orta' kelimesinin de ortaoyunu temsillerini akla getirdiğini iddia etmişlerdir. Oysa Sünbül-zâde Vehbi'nin bu beytinde ortaoyunu geleneğini kastetmediği aşikârdır." (Aykaç, 2019: 31)

Yine birinci bölümde dikkati çeken bir diğer husus, Aykaç'ın ortaoyunu temsillerinin bölümlerine dair tespitidir. "Bugüne kadar yayımlanan kitap ve makalelerde ortaoyunu temsilleri 'giriş, muhavere, fasıl, bitiş' şeklinde bölümlenip 'curcuna' ve 'ara fasıl' bölümleri ya hiç anılmamış ya da bir-iki satır açıklamayla geçiştirilmiştir." (Aykaç, 2019: 41) diye söze başlayan Aykaç, en az birkaç yüzyıl boyunca temsillerde varlığını sürdüren 'curcuna' ve 'ara fasıl' bölümlerini de ayrı başlıklar altında ele almış ve bu bölümlerin belli başlı özelliklerini dile getirmiştir.

Aykaç'ın çalışması, ikinci bölümde (ss. 109-170) daha çok metinlerin yapı ve içerik çözümlemesi ile seyircilerin temsildeki rolüne yoğunlaşmıştır. "Ortaoyunu Metinlerinde Kurgu” üst başlığını taşıyan bu bölümde Aykaç; ortaoyunu metinlerinin yeniden yazım sürecinde geçirdiği değişimi, "estetik uzaklık" kavramı üzerinden oyun-oyuncu-seyirci bağını, gülme teorilerine göre oyun metinlerinin içeriğini ve ortaoyunu seyircisinin genel özelliklerini incelemiştir. Aykaç, bir senaryo olarak ele alınabilecek ortaoyunu metinlerini yeniden yazım başlığıyla değerlendirmeye almış; "Telgrafçı”, "Fotoğrafçı”, "Büyücü” ve "Kanlı Nigar" oyunlarını bu kategoride değerlendirmiştir. Estetik uzaklık konusu ise Aykaç'ın metin ve bağlam ilişkisini sorguladığı bir bölüm olarak dikkati çekmektedir. Burada Aykaç; "oyun alanı üzerinden”, "dekor üzerinden”, "hareket komiği üzerinden", "kurmaca âlem vurgusuyla" sağlanan estetik uzaklık unsurlarına etraflıca yer vermiştir. Ardından gülme teorilerine göre metinleri değerlendiren Aykaç'ın; üstünlük (kötüleme), uyumsuzluk (uyuşmazlık) ve rahatlama (psikanalitik) teorilerine göre metinlerdeki güldürü unsurlarını ortaya çıkardığı görülmektedir. Kitabın ikinci bölümü, temsillerdeki seyirci-oyuncu etkileşiminin irdelenmesiyle son bulmaktadır. Aykaç, seyirci-oyuncu etkileşimini ele alırken bilhassa alanın ustalarının hatıralarından ve dönemin gazete haberlerinden faydalanmıştır.

İkinci bölümün en dikkate değer satırları, hiç şüphesiz, "Estetik Uzaklık Kavramı ve Ortaoyunu" başlığı altında yer almaktadır. Bertolt Brecht'in çalışmalarında "verfremdung" olarak geçen ve Türkçeye "yabancılaştırma" şeklinde çevrilen terime -Sevda Şener'in kullandığ 1 hâliyle- "estetik uzaklık" demeyi tercih eden Aykaç, ortaoyunu temsillerinde görülen estetik uzaklık unsurlarını yeni baştan tasnif etme ihtiyacını duymuştur. Bunun gerekçesini ise şu şekilde ifade etmiştir: "Estetik uzaklık kavramının ortaoyunuyla bağını belirli bir sistem dâhilinde inceleyen ilk araştırmacılardan biri Özdemir Nutku'dur. Nutku, 'estetik uzaklık' yerine 'yabancılaştırma' terimini kullanmayı tercih etmiş ve 6 oyundan (Ödüllü, Büyücü Hoca, Eskici Abdi, Gülme Komşuna/Kütahya, Tahir ile Zühre, 
Fotoğrafçı) seçtiği örnekler eşliğinde ortaoyunu temsillerinde yanılsamayı bozan unsurları 4'e ayırmıştır: 'Metinde yabancılaştırma, oyunculukta yabancılaştırma, dekorda yabancılaştırma, sahne ile seyirci arasında yabancılaştırma'. Ne var ki Özdemir Nutku'nun yapmış olduğu tasnif, incelemeye tabi tutulan 43 oyunun tümünde görülen estetik uzaklık unsurlarını kapsamakta yetersiz kalmaktadır. $\mathrm{Bu}$ eksikliği giderebilmek adına 'hareket komiği üzerinden sağlanan estetik uzaklık, oyun alanının genişliği üzerinden sağlanan estetik uzaklık, dekor üzerinden sağlanan estetik uzaklık, kurmaca âlem vurgusuyla sağlanan estetik uzaklık' şeklinde yeni bir tasnife gitmek faydalı olacaktır." (Aykaç, 2019: 127) Aykaç'ın bu satırların devamında verdiği örnekler, yeni tasnifin başarılı olduğunu ve Özdemir Nutku'nun açık bıraktığı noktaları bu tasnifin tamamladığını göstermektedir.

$\mathrm{Bu}$ arada, Aykaç'ın tezini bilim dünyasına duyurmak için yayımlamış olduğu "Uyumsuzluk (Uyuşmazlık) Teorisi Bağlamında Ortaoyunu Metinlerinin İncelenmesi" (Aykaç, 2016) başlıklı makalesini, bu bölümde yer alan "Gülme Teorileri Bakımından Ortaoyunu" başlığının bir kısmından türettiğini de burada söylemek gerekir.

Kitabın “Ortaoyunu Metinlerinde Halk Kültürü Unsurları” başlıklı üçüncü bölümü (ss. 171-208), ortaoyunu metinlerine yansıyan halk kültürü unsurlarına ayrılmıştır. Halk kültürü unsurlarıyla ilgili Sedat Veyis Örnek'in tasnifi (Örnek, 1977: 17-20) dikkate alınmış, tasnifin yetersiz kaldığı kısımlarda Aykaç tarafından bazı eklemeler yapılmıştır. Halkın günlük hayatının bir parçası olan yeme içme alışkanlıkları, inançlar, gelenek ve görenekler, halk hekimliği, geçiş dönemleri vs. metinlerden seçilen örnekler eşliğinde anlatılarak ortaoyununun halk hayatıyla bağı ortaya konulmuştur. Böylece, oyunlar kurgulanırken yararlanılan yerli ögeler büyük oranda tespit edilmiştir.

Geçmişten Günümüze Ortaoyunu Geleneği adlı çalışma, genel bir değerlendirmeyi içeren "Sonuç" (ss. 209-212); yararlanılan materyalleri gösteren "Kaynakça" (ss. 213-229); Utku Erişik, Hasan Hüseyin Karabağ ve Alpay Ekler'le gerçekleştirilen mülakatların metinlerinden oluşan "Ekler" (ss. 230-255) başlıklarıyla son bulmaktadır.

Onur Aykaç'ın da eser için yazdığı önsözde belirttiği üzere, bu eserin ortaoyunu üzerine yapılacak yeni araştırmalara kapı aralaması dileğiyle...

\section{Kaynakça}

AYKAÇ, Onur (2016). Uyumsuzluk (uyuşmazlık) teorisi bağlamında ortaoyunu metinlerinin incelenmesi. Selçuk Üniversitesi Edebiyat Fakültesi Dergisi (SEFAD), 35, 235-244.

AYKAÇ, Onur (2019). Geçmişten günümüze ortaoyunu geleneği. Ankara: Akçağ Yayınları. 
BEN-AMOS, Dan (2006). Şartlar ve çevre içinde folklorun bir tanımına doğru. Çev.: Metin Ekici. Halkbiliminde kuramlar ve yaklaşımlar 1. Ankara: Geleneksel Yayıncılık.

ÖRNEK, Sedat Veyis (1977). Türk halkbilimi. Ankara: İş Bankası Kültür Yayınları. 